(2) Open Access Full Text Article

REVIEW

\title{
Orphan drugs in development for primary biliary cirrhosis: challenges and progress
}

This article was published in the following Dove Press journal:

Orphan Drugs: Research and Reviews

10 September 2015

Number of times this article has been viewed

\author{
Ahmad $\mathrm{H} \mathrm{Ali}^{\prime}$ \\ Thomas J Byrne' \\ Keith D Lindor ${ }^{1,2}$ \\ 'Division of Gastroenterology and \\ Hepatology, Mayo Clinic, ${ }^{2}$ College \\ of Health Solutions, Arizona State \\ University, Phoenix, AZ, USA
}

Correspondence: Ahmad H Ali Division of Gastroenterology and Hepatology, Mayo Clinic, 13400 East Shea Boulevard, Scottsdale, AZ 85259, USA

Tel + I 8062822254

Fax + I 480 83| 0665

Email ali.ahmad@mayo.edu
Abstract: Primary biliary cirrhosis (PBC) is a chronic progressive liver disease that often leads to fibrosis, cirrhosis, and end-stage liver disease. The diagnosis is made when there is evidence of cholestasis and reactivity to the antimitochondrial antibody. The etiology of PBC is poorly understood; however, several lines of evidence suggest an environmental factor that triggers a series of immune-mediated inflammatory reactions in the bile ducts in a genetically susceptible individual. Fatigue and pruritus are the most common symptoms of PBC; however, many patients are diagnosed with PBC only based on laboratory abnormalities. The only pharmacological treatment approved for PBC is ursodeoxycholic acid (UDCA). Several controlled studies have shown that UDCA improves liver biochemistries and prolongs transplant-free survival in PBC patients. Nearly $40 \%$ of PBC patients do not respond to UDCA, and those patients are at high risk of serious adverse events, such as the development of liver failure. Therefore, newer alternative therapeutic options for PBC are needed. Obeticholic acid is a first-in-class farnesoid $\mathrm{X}$ receptor agonist that has been recently evaluated in $\mathrm{PBC}$ patients with inadequate response to UDCA, and demonstrated beneficial results in improving liver biochemistries. Several other agents (fibrates and glucocorticoids) have been previously examined in PBC patients with inadequate response to UDCA, and preliminary results showed biochemical improvement. However, large-scale controlled clinical trials are needed to determine the long-term effects of fibrates and glucocorticoids on the clinical outcomes of PBC. Clinical trials of NGM282 (a fibroblast growth factor-19 analog) and Abatacept (a fusion protein composed of the Fc portion of immunoglobulin G1 fused to CTLA4) are currently underway.

Keywords: primary biliary cirrhosis, antimitochondrial antibody, farnesoid $\mathrm{X}$ receptor, fibrates, glucocorticoids

\section{Introduction}

\section{Definition and significance of primary biliary cirrhosis}

Primary biliary cirrhosis $(\mathrm{PBC})$ is a relatively rare but important cause of liver disease in the Western society. The disease affects $<200,000$ individuals in the USA and has been designated as an orphan disease by the US Food and Drug Administration. ${ }^{1}$ Recent PBC epidemiological studies in North America, Europe, and Australia have reported a prevalence of 1.9-40.2 per 100,000 population and an incidence of 0.39-9.8 per 100,000 population. ${ }^{2}$ Since it was first described in the year 1851 by Addison and Gull, ${ }^{3}$ significant progress has been made in the diagnosis and management of PBC.

$\mathrm{PBC}$ is an autoimmune disease characterized histologically by chronic inflammation and destruction of the interlobular bile ducts and affects women more commonly than men (ratio 10:1). ${ }^{4}$ The sera of nearly $95 \%$ of patients with PBC test positive 
for the antimitochondrial antibody (AMA), and the most common biochemical abnormality in PBC is an elevated serum alkaline phosphatase (ALP) level. ${ }^{5}$ The diagnosis of PBC can be made when two of the following criteria are met (provided that other causes of intra- and extrahepatic cholestasis have been excluded): 1) evidence of cholestasis based on serum ALP elevation, 2) the presence of AMA, and 3) histological evidence of PBC. These criteria are endorsed by the American Association for the Study of Liver Diseases and the European Association for the Study of the Liver., ${ }^{5,6}$

AMA is an autoantibody found in the majority of patients with PBC ( $\sim 95 \%)$ and targets a family of mitochondrial enzymes named the 2-oxo-acid dehydrogenase complexes. ${ }^{7-9}$ The levels of AMA may vary through the course of PBC, and there seems to be no relationship between the AMA level and the degree of severity or stage of PBC. ${ }^{5}$ Enzyme-linked immunosorbent assay, immunoblotting, and indirect immunofluorescence are the most common methods used for AMA detection. ${ }^{9}$ AMA is rarely found in healthy individuals, with a reported prevalence rate ranging from $0.5 \%$ to $2 \%$. $^{10-13}$

\section{Presentation of and conditions associated with PBC}

$\mathrm{PBC}$ is often diagnosed in a preclinical asymptomatic phase, after screening liver blood tests have been ordered by a primary care provider. ${ }^{14}$ Fatigue ${ }^{15-19}$ and pruritus ${ }^{20-23}$ are the most frequent symptoms of PBC, present in $60 \%-80 \%$ and $20 \%-70 \%$ of patients, respectively, and both have a marked negative impact on the quality of life of patients with PBC. Other manifestations of PBC include xanthomas and xanthelasmas (from underlying associated hyperlipidemia), vitamin D deficiency, osteopenia, and osteoporosis. ${ }^{14}$ When PBC has progressed to stage IV fibrosis (cirrhosis), portal hypertension may ensue with hepatomegaly, splenomegaly, ascites, varices, hepatic encephalopathy, and jaundice. ${ }^{5}$ Fatigue in PBC may lead to inability to work, depression, poor quality of life, more aggressive disease, and decreased survival. ${ }^{15-17,24-31}$ Pruritus has been associated with severe excoriations, skin bleeding, inability to sleep, and more aggressive disease. ${ }^{22,30,32-40}$ Severe pruritus can be very debilitating and is considered an acceptable indication for liver transplantation regardless of Child-Turcotte-Pugh or model for end-stage liver disease score by some centers. ${ }^{16,36,41}$ $\mathrm{PBC}$ is associated with other autoimmune intra- and extrahepatic conditions such as autoimmune hepatitis, ${ }^{42-45}$ Sjogren's syndrome, arthritis, ${ }^{46}$ thyroid diseases, scleroderma, Raynaud's phenomenon, type I diabetes mellitus, systemic lupus erythematosus, and celiac disease. ${ }^{47}$

\section{Etiology and pathogenesis of PBC}

The cause of $\mathrm{PBC}$ remains unidentified. There is increasing evidence that $\mathrm{PBC}$ is caused by an environmental factor that triggers a series of inflammatory reactions in a genetically susceptible host, leading to PBC. ${ }^{48,49}$ Cigarette smoking, infections (particularly urinary tract and Helicobacter pylori infections), the use of hormone replacement therapies, and frequent use of nail polish have been found to be associated with an increased risk of $\mathrm{PBC} .^{50-53}$ The strong spatial variation of risk and clustering of $\mathrm{PBC}$ cases in certain geographical areas around the world (around superfund toxic waste sites in New York City, ${ }^{54}$ near the Revelin reservoir in England, ${ }^{55}$ the Tyneside region in Northeast England, ${ }^{49}$ and in Hiroshima among the survivors of the atomic bomb ${ }^{56}$ ) suggest that one or more environmental risk factors are implicated in the pathogenesis of $\mathrm{PBC}$, and that toxin exposure may be responsible for the clustering of PBC cases. In PBC, humoral and cellular immune responses are exaggerated, likely due to the loss of tolerance to self-antigens. ${ }^{57,58} \mathrm{PBC}$ patients frequently exhibit high levels of serum autoantibodies (immunoglobulin [Ig] M, IgG, and IgA) and significantly increased numbers of cytotoxic $\mathrm{T}\left(\mathrm{CD}^{+}\right)$and helper $\mathrm{T}\left(\mathrm{CD} 4^{+}\right)$lymphocytes compared to control subjects. ${ }^{57-63}$ Helper $\mathrm{T}\left(\mathrm{CD}^{+}\right)$lymphocytes release cytokines (such as interleukin [IL]-1, IL-2, IL-4, IL-6, interferon- $\gamma$ ) that activate cytotoxic $\mathrm{T}\left(\mathrm{CD} 8^{+}\right)$ lymphocytes, which in turn directly destroy the hepatocytes and cholangiocytes. ${ }^{64-66}$ In addition, the cytokines released by the helper T $\left(\mathrm{CD}^{+}\right)$lymphocytes recruit natural killer cells, which contribute to the destruction of biliary epithelium..$^{57,64}$ The overexpression of the major histocompatibility complex (MHC)-I and MHC-II is believed to contribute to the local liver tissue damage that occurs in $\mathrm{PBC}$, as they enable the recognition of the self-antigens by the activated lymphocytes, leading to further destruction of the portal tracts and surrounding hepatic tissue. ${ }^{57,58}$

It is strongly believed that accumulation of the toxic hydrophobic bile acids in the liver tissue contributes to the liver damage that occurs in PBC. ${ }^{67-69}$ Therefore, modulation of the bile acid pool or removal of the toxic hydrophobic bile acids would theoretically have beneficial effects in patients with PBC. Acting through this mechanism, it is believed that ursodeoxycholic acid (UDCA, a naturally occurring hydrophilic bile acid, and the only agent approved by the US Food and Drug Administration for the treatment of PBC) enriches the total bile acid pool by replacing the unwanted toxic bile acids, ${ }^{70}$ which can have deleterious effects on the liver tissue. For example, in mice, lithocholic acid has been found to promote destruction of the portal tracts and bile ducts. ${ }^{71}$ 
An Australian group ${ }^{72}$ monitored 12 patients with PBC and six patients with primary sclerosing cholangitis over a 4-year period. They found that patients with a serum total chenodeoxycholic acid (CDCA) concentration at study entry that exceeded $15 \mu \mathrm{mol} / \mathrm{L}$ were 10 times more likely to die from liver disease or need a liver transplant in the following 4 years than patients with CDCA levels $<15 \mu \mathrm{mol} / \mathrm{L}$.

\section{Genetics of PBC}

In addition to environmental factors, genetic predisposition is believed to play an important role in the development of PBC. ${ }^{48}$ Data from genetics-based studies have shown that first-degree family members of $\mathrm{PBC}$ patients are at high risk of PBC. In one study, the prevalence of $\mathrm{PBC}$ has been reported to be 720 per 100,000 and 1,200 per 100,000 in first-degree relatives and offspring of affected individuals, respectively. ${ }^{73}$ In addition, the prevalence of positive AMA (without clinical or biochemical evidence of $\mathrm{PBC}$ ) is high among first-degree relatives of $\mathrm{PBC}$ patients; one study found that $20 \%$ of sisters, $15 \%$ of mothers, and $10 \%$ of daughters of $\mathrm{PBC}$ patients were seropositive for AMA. ${ }^{74}$ The clinical significance of AMA seropositivity in first-degree relatives of $\mathrm{PBC}$ patients remains unclear. The genome-wide associated studies have identified important gene alleles believed to be related to PBC..$^{73,75-80}$

\section{Natural history and outcomes of PBC}

The progression and outcome of $\mathrm{PBC}$ depend on various clinical and biochemical factors at the time of diagnosis. Asymptomatic $\mathrm{PBC}$ patients have a better survival compared to patients who have symptoms at the time of diagnosis of PBC, and approximately two-third of asymptomatic PBC patients develop symptoms over a median time interval of 4.2-5.3 years of follow-up. ${ }^{81-86}$ PBC patients have worse survival than the general healthy population, irrespective of the presence or absence of symptoms at the time of diagnosis. ${ }^{5}$ Risk factors that have been associated with poor prognosis of $\mathrm{PBC}$ are male sex, the presence of symptoms at diagnosis of PBC, elevated serum bilirubin, elevated serum ALP, the presence of anti-Sp100 and anti-gp210 autoantibodies, prolonged prothrombin time, development of esophageal varices, inadequate response to UDCA, and advanced histological stage..$^{83,87-94}$ Despite its rarity, $\mathrm{PBC}$ remains an important cause of morbidity in the Western world. Many patients with $\mathrm{PBC}$ progress to cirrhosis and end-stage liver disease, requiring liver transplantation. ${ }^{95} \mathrm{PBC}$ is one of the leading indications for liver transplantation. ${ }^{41,95,96}$ Moreover, $\mathrm{PBC}$ has been identified as an important risk factor for hepatocellular carcinoma. ${ }^{93,97-102}$

\section{Current pharmacological treatment of PBC}

UDCA is the only drug approved by the US Food and Drug Administration for the treatment of PBC. Several controlled and uncontrolled clinical trials have shown that UDCA improves liver biochemistries, delays histological progression, delays development of esophageal varices, and improves the transplant-free survival in patients with PBC. ${ }^{103-111}$ UDCA is $3 \alpha, 7 \beta$-dihydroxy-5 $\beta$-cholanoic acid, a bile acid with two hydroxy groups $(-\mathrm{OH})$ at positions 3 and 7 in the cholane ring structure, with an $\alpha$ - and $\beta$-orientation, respectively. ${ }^{12}$ The $\mathrm{C}-7 \beta$-orientation confers the molecule a far higher hydrophilicity than that of its structural analog with an $\alpha$-orientation, CDCA. ${ }^{12}$

The exact mechanism of action of UDCA in PBC has not been established yet. However, there are a number of proposed mechanisms by which UDCA is thought to exert its beneficial effects in PBC. First, UDCA changes the hydrophobicity index of the endogenous bile acid pool and replaces the potentially toxic hydrophobic bile acids by enriching the endogenous bile acid pool. ${ }^{70,112}$ UDCA comprises no more than $4 \%$ of the total endogenous bile acid pool in healthy individuals, whereas this percentage is increased to $40 \%-60 \%$ in individuals taking conventional UDCA doses of $13-15 \mathrm{mg} / \mathrm{kg}$ body weight per day. ${ }^{113}$ Depending on the dose used, UDCA enriches the bile acid pool, accounting for $19 \%-64 \%$ of the total biliary bile acids. ${ }^{114}$ These effects are thought to protect the liver tissue against the deleterious effects of detergent bile acids. Second, UDCA protects hepatocytes and cholangiocytes against cell death induced by the cytotoxic bile acids by counteracting the extrinsic and intrinsic apoptotic pathways responsible for the hepatocyte and cholangiocyte damage in PBC. ${ }^{112}$ Third, UDCA decreases the intracellular concentration of bile acids and favors their elimination through the urinary route by preventing the uptake of bile acids by hepatocytes (by downregulating the organic anion-transporting polypeptide 1 , a basolateral transporter involved in bile acid hepatocyte uptake), ${ }^{115}$ enhancing the excretion of conjugated bile acids into the blood (by upregulating the basolateral export pumps multidrug resistance-associated protein [Mrp] 3 and Mrp4), ${ }^{116-118}$ repressing bile acid synthesis, ${ }^{119}$ and eliminating the toxic bile acids through the kidneys (by upregulating the renal apical bile acid export pumps Mrp2 and Mrp4). ${ }^{116,120-122}$ Fourth, UDCA reduces portal inflammation and ductular proliferation and preserves bile duct integrity by stimulating $\mathrm{HCO}_{3}^{-}$secretion by the cholangiocytes. ${ }^{123-125} \mathrm{HCO}_{3}^{-}$secretion is thought to improve the bile flow through the affected 
bile ducts, thus ameliorating the deleterious effects of toxic bile acids on the liver tissue. ${ }^{126}$ Fifth, UDCA exerts immunomodulatory and anti-inflammatory effects on the humoral and cellular immune responses by suppressing the production of autoantibodies, ${ }^{127}$ suppressing the cytotoxic $\mathrm{T}\left(\mathrm{CD}^{+}\right)$and helper $\mathrm{T}\left(\mathrm{CD}^{+}\right)$lymphocytes, ${ }^{127,128}$ inhibiting the release of cytokines produced by immune cells (IL-2, IL-4, interferon- $\gamma$, and tumor necrosis factor- $\alpha$ ), ${ }^{127,129-132}$ and inhibiting the overexpression of cell surface molecules such as MHC-I, MHC-II, intercellular adhesion molecule-1, and lymphocyte function-associated antigen-1. ${ }^{133-135}$

\section{Progress in the treatment of PBC}

Despite the proven efficacy of UDCA in PBC, nearly $40 \%$ of $\mathrm{PBC}$ patients do not respond adequately to treatment with UDCA. ${ }^{136}$ There are several criteria proposed to define biochemical response and nonresponse to UDCA therapy: ${ }^{89,136-140}$ the Mayo Clinic criteria ${ }^{137}$ (serum ALP decrease to $<2$ times the upper limit of normal [ULN] at 6 months of UDCA treatment), Barcelona criteria ${ }^{136}$ (serum ALP decrease to $>40 \%$ from baseline or to normal value after 12 months of UDCA treatment), Paris criteria ${ }^{89}$ (decrease in serum ALP to $\leq 3$ times ULN, decrease in serum aspartate aminotransferase to $\leq 2$ times ULN, and normal serum bilirubin after 12 months of UDCA treatment), Toronto criteria $^{141}$ (decrease in serum ALP to $\leq 1.67$ times ULN after 12 months of UDCA treatment), and the Rotterdam criteria $^{139}$ (normalization of serum bilirubin and albumin after 12 months of UDCA treatment when one or both parameters were abnormal before treatment, or normalization of serum bilirubin or albumin after 12 months of UDCA treatment when both were abnormal before treatment). These criteria of biochemical response to UDCA have now become surrogate markers of therapeutic efficacy in PBC. PBC patients who have suboptimal biochemical response to UDCA treatment are at risk of late and serious complications, such as development of liver cirrhosis, hepatocellular carcinoma, and signs of portal hypertension, ${ }^{14}$ and therefore, newer treatments for PBC are needed, as discussed later.

\section{Farnesoid $\mathrm{X}$ receptor agonists and $\mathrm{PBC}$}

Farnesoid X receptors (FXRs) ${ }^{142}$ are nuclear hormone receptors expressed in high quantities in tissues that are involved in bile acid, carbohydrate, and lipid metabolism, such as the liver and intestines. ${ }^{143}$ Manipulation of FXR is a breakthrough that has significantly improved our understanding of bile acid metabolism, and it also opened new therapeutic avenues for many liver disorders such as nonalcoholic fatty liver disease and cholestatic liver diseases.

\section{Rationale for use}

FXRs have been found to be important, key regulators of bile acid metabolism in humans. ${ }^{143}$ When activated, FXR modulates the bile acid size and pool composition by reducing the production of endogenous bile acids through suppression of the gene encoding the enzyme cholesterol $7 \alpha$-hydroxylase, the rate-limiting step in the biosynthesis of endogenous bile acids. ${ }^{144}$ The reduction of the total bile acid pool decreases the bile acid workload on the liver, with beneficial effects on liver health and regeneration capacity. ${ }^{145}$ Bile acids have been found to be natural ligands of FXR. ${ }^{144}$ In addition to directly suppressing the gene encoding the enzyme cholesterol $7 \alpha$-hydroxylase, FXR activation has been found to indirectly suppress cholesterol $7 \alpha$-hydroxylase through regulating the expression of an intestinal growth factor named fibroblast growth factor-19 (FGF-19). ${ }^{146,147}$ FGF-19 has been found to suppress the expression of cholesterol $7 \alpha$-hydroxylase in human hepatocytes through a c-Jun N-terminal kinase-dependent pathway. ${ }^{148}$ FXR also plays a key role in the enterohepatic circulation, as activation of FXR results in expression of the cytosolic intestinal bile acid-binding protein. ${ }^{149}$ This protein facilitates the movement of bile acids from the intestines through the enterocytes into the portal circulation. ${ }^{150}$

Preclinical experiments have shown that FXR activation protects against bile acid-related injury to the liver, prevents development of liver fibrosis, and exerts immunoregulatory effects on cells of innate immunity. ${ }^{151,152}$ Collectively, these effects could be of therapeutic benefit to patients with cholestatic liver diseases. Obeticholic acid (OCA), also known as INT-747, is a first-in-class selective FXR agonist. It is a $6 \alpha$-ethyl derivative of CDCA and selectively binds to FXR, with $\sim 100$-fold greater binding affinity to FXR than to $\mathrm{CDCA} .{ }^{152}$

\section{Clinical experience}

OCA has been recently investigated in 165 patients with $\mathrm{PBC}$ who had an inadequate response to UDCA. ${ }^{153}$ In this Phase II clinical trial, patients with $\mathrm{PBC}$ and inadequate response to UDCA were initially randomized to either placebo or one of the three OCA treatment groups $(10 \mathrm{mg}, 25 \mathrm{mg}$, and $50 \mathrm{mg}$ per day) for 3 months. All patients continued UDCA treatment on a stable dose throughout the study period. After completion of the initial 3 months of treatment (the randomized placebo-controlled phase), 78 patients continued treatment 
with OCA in an open-label extension clinical trial for 12 more months. ${ }^{153}$ The primary endpoint was the percentage change in serum ALP from baseline value (on day 0 ) to the end of treatment in the randomized placebo-controlled phase (day 85). Patients in the OCA treatment groups experienced significant reductions in serum ALP, $\gamma$-glutamyl transpeptidase (GGTP), alanine aminotransferase, aspartate aminotransferase, and bilirubin levels, compared to patients in the placebo group. ${ }^{153}$ Specifically, mean serum ALP reduced from baseline values by $24 \%, 25 \%$, and $21 \%$ in the OCA $10 \mathrm{mg}$, OCA $25 \mathrm{mg}$, and OCA $50 \mathrm{mg}$ per day groups, respectively, compared to only a $3 \%$ reduction in serum ALP in the placebo group. Statistically significant change in serum ALP values in the OCA groups was observed as early as 2 weeks of treatment. ${ }^{153}$ Only 7\% (7/99) of patients in the OCA groups experienced normalization of serum ALP compared to none in the placebo group. Pruritus was the principal side effect in the OCA treatment groups: 92/127 (72.4\%) compared to $19 / 38(50 \%)$ in the placebo group. ${ }^{153}$ The incidence and severity of pruritus were worse in the intermediate- and high-dose OCA treatment groups. The incidence of pruritus in the open-label extension trial phase was $87 \%$ (68/78), and 13\% (10/78) discontinued OCA due to severe pruritus. Patients who were enrolled in the openlabel extension clinical trial maintained biochemical response throughout the 12-month treatment period.

Patients in the OCA treatment groups (low, intermediate, and high dose) experienced significant reductions in serum ALP by the end of treatment, and this is important because ALP is a prognostic marker in PBC patients. In a recent meta-analysis involving 4,845 $\mathrm{PBC}$ patients from 15 North American and European clinical centers, ${ }^{87}$ ALP was a strong predictor of clinical outcomes (liver transplantation or death), and PBC patients who experienced ALP reduction had better survival than those who had persistently elevated serum ALP levels. ${ }^{87}$ Although the mean serum bilirubin levels were normal for patients enrolled in this study, PBC patients in the intermediate-dose and high-dose OCA treatment groups experienced statistically significant reductions in their serum bilirubin by the end of treatment. This is another potentially important finding, because elevated bilirubin is the strongest predictor of clinical outcomes and survival in patients with PBC. ${ }^{154}$ Mean serum ALP levels continued to further decrease in the group of patients who were enrolled in the openlabel extension trial phase $(285 \pm 15 \mathrm{U} / \mathrm{L}$ at baseline versus $210 \pm 12 \mathrm{U} / \mathrm{L}$ at 3 months versus $202 \pm 11 \mathrm{U} / \mathrm{L}$ at 12 months of OCA treatment), suggesting that OCA treatment in patients with $\mathrm{PBC}$ should be continued for at least 1 year, if not indefinitely, to observe the desired effect of OCA on the long-term outcomes of PBC.

There are several questions that remain to be answered: 1) What is the effect of the combination therapy of OCA and UDCA on the clinical course and long-term outcomes of PBC? 2) What are the long-term side effects and adverse events related to OCA alone, and to the combination therapy of OCA and UDCA, if any? 3) What is the effect of OCA monotherapy on short- and long-term outcomes in PBC patients? Clearly, to answer these questions, large-scale and long-term controlled clinical trials are needed.

\section{Fibrates and PBC}

Fibrates (fenofibrate and bezafibrate) are fibric acid derivatives that are widely used for the treatment of hyperlipidemia and hypertriglyceridemia. Fibrates act mainly by suppressing acetyl coenzyme A carboxylase. ${ }^{155}$ The peroxisome proliferator-activated receptors (PPARs) are the main molecular targets of fibrates. ${ }^{156}$ There are three distinct isoforms of PPARs in humans that are encoded by distinct genes: PPAR- $\alpha$, PPAR $-\delta$, and PPAR $-\gamma \cdot{ }^{157}$ PPAR- $\alpha$ is highly expressed in tissues that participate in lipid metabolism, such as the liver, kidney, heart, and skeletal muscle, and activation of PPAR- $\alpha$ results in $\beta$-oxidative degradation of fatty acids and regulation of transcription of genes involved in lipid metabolism. ${ }^{158,159}$ Fibrates exhibit different potencies to all three human isoforms of PPARs. ${ }^{157}$

\section{Rationale for use}

In 1999, Iwasaki et al noted that patients with hypercholesterolemia experienced significant reductions in serum ALP, GGTP, and IgM when they were started on bezafibrate. ${ }^{160}$ Based on these events, they suggested that treatment with fibrates might be of therapeutic benefit in patients suffering from cholestatic liver disease. Since then, significant biochemical improvement in patients with $\mathrm{PBC}$ receiving fibrates (bezafibrate and fenofibrate) has been reported across several pilot studies, and Phase III clinical trials are needed. ${ }^{161}$

Although the exact mechanism of action of fibrates in cholestatic liver diseases remains unclear, several hypotheses have been proposed. PPAR- $\alpha$ activation results in downregulation of bile acid synthesis by inhibiting cholesterol $7 \alpha$-hydroxylase and sterol 27 -hydroxylase ${ }^{162}$ and regulation of bile acid detoxification by upregulation of uridine 5'-diphospho-glucuronosyltransferase 2B4, cytochrome P450 3A4, apical sodium-dependent bile acid transporter (ASBT), and sulfotransferase 2A1. ${ }^{159,163-165}$ 
These induced changes in bile acid metabolism are thought to be beneficial in patients with cholestatic liver diseases. Fibrates have been found to directly enhance biliary excretion of phosphatidylcholine by upregulation of the Mrp3 through stimulation of PPAR- $\alpha .{ }^{166}$ This activity is thought to be important because it aids in the excretion of the toxic hydrophobic bile acids by forming hydrophilic compounds and micelles. In animal models, fibrates minimize the degree of injury induced by cholestasis by upregulation of the Mrp4 and Mrp3. ${ }^{167}$ These proteins are normally expressed in the basolateral surfaces of the hepatocytes and play a crucial role in the efflux of bile acids into the systemic circulation. ${ }^{168} \mathrm{In}$ cholestasis, their upregulation is therapeutically important because it is believed to be a defensive mechanism by which the liver minimizes the tissue damage caused by cholestasis. ${ }^{169}$

Nitric oxide (NO) production pathway is an attractive therapeutic target in many diseases. NO production is catalyzed by the enzyme nitric oxidase synthase.${ }^{170} \mathrm{In}$ inflammatory and autoimmune states, $\mathrm{NO}$ contributes to the tissue inflammation by damaging the mitochondria and inducing proinflammatory cytokines. ${ }^{170}$ Increased levels of NO in the sera and increased expression of nitric oxidase synthase at the site of damaged biliary epithelial cells have been reported in PBC. ${ }^{171-173}$ It has been proposed that fibrates ameliorate portal tract inflammation and bile duct injury in PBC by downregulation of NO production. ${ }^{174}$

Fibrates have also been found to inhibit migration of immune cells to the liver in PBC by decreasing the expression of bile acid-induced regulated upon activation normal T-cell expressed and secreted (RANTES) and by inhibiting DNA-binding activity and transcriptional activity of nuclear factor kappa B (NF- $\mathrm{KB}) \cdot{ }^{175}$ In addition, fibrates may also have immunoregulatory effects in $\mathrm{PBC}$ such as inhibiting $\mathrm{CD} 4{ }^{+} \mathrm{CD} 25^{+}$regulatory T-cells (Tregs) apoptosis induced by B-cell activating factor. ${ }^{176}$ Tregs play a critical role in controlling the production of inflammatory cytokines by the activated immune cells in autoimmune conditions such as PBC. ${ }^{176}$

In patients with $\mathrm{PBC}$, the addition of bezafibrate to UDCA improved the serum hepatic fibrosis parameters, ${ }^{177}$ suggesting that fibrates not only act as inflammatory agents in PBC but also act as antifibrotic agents. A recent study has shown that fibrates act as both PPAR- $\alpha$ and pregnane $X$ receptor (PXR) agonists. ${ }^{178}$ Collectively, these data suggest that fibrates might be of therapeutic benefit in patients with cholestatic liver diseases.

\section{Clinical experience}

Several pilot studies have consistently shown that fibrates might be of therapeutic benefits in patients with cholestatic liver diseases, particularly PBC. ${ }^{160,179-192}$ The use of fibrates in PBC has demonstrated satisfactory outcomes with an excellent safety profile, and although results are preliminary, data suggest that fibrates are beneficial in PBC. However, large-scale multicenter clinical trials are awaited. Most of the studies reported the use of fibrates in addition to UDCA in PBC patients with insufficient response to UDCA, and fibrates are not approved by the federal health agencies for the treatment of PBC. Only one pilot study reported the use of bezafibrate alone compared to UDCA in PBC patients. ${ }^{182}$ In this clinical trial, patients in the bezafibrate group showed more significant improvement in liver biochemistries compared to patients in the UDCA group. ${ }^{182}$

Fibrate use results in significant reduction in cholestatic parameters (serum ALP and GGTP), transaminases, and IgM levels in PBC. ${ }^{160,179,182-184,189-192}$ Effects of fibrates on the biochemical parameters can be observed as early as 1 month of the beginning of therapy, and most patients sustained the biochemical response as long as they were on fibrates. Discontinuation of fibrates results in rebound elevation of biochemical indices in patients with $\mathrm{PBC}$, and an improvement in the biochemical indices is almost always observed after treatment with fibrates is reinstituted, further supporting the potential therapeutic benefit in $\mathrm{PBC}$. The effects of fibrates on the histological progression of PBC have been reported from only two studies; one study showed amelioration of portal tract inflammation and cholangitis in two out of three cases of PBC, ${ }^{187}$ and another study showed no significant change in follow-up histological evaluation in one case and histological progression in the other case of PBC. ${ }^{181}$

Almost all studies have shown a remarkable reduction in serum IgM when measured, and whether this change is of prognostic importance in PBC patients receiving fibrates is unclear. In addition to the biochemical improvement, significant pruritus relief has been observed in patients with PBC with inadequate response to UDCA following institution of fibrate therapy. ${ }^{183}$ Patients experienced worsening of pruritus when bezafibrate was discontinued, and pruritus improved or completely disappeared after bezafibrate was reinstituted. ${ }^{183}$ These data lend support to the use of fibrates in PBC patients, and suggest that fibrates could be used in the management of pruritus.

Data from a preliminary Spanish study examining the effects of bezafibrate on symptoms and hepatic biochemical 
indices in PBC patients with inadequate response to UDCA suggest that patients with early-stage $\mathrm{PBC}$ benefit more from the combination therapy than patients with advanced-stage PBC. ${ }^{183}$ These results need to be verified in a large-scale, long-term clinical trial.

The use of fibrates in PBC patients (alone or in combination with UDCA) has been shown to be generally safe and well tolerated. Heartburn and nausea are the most commonly reported side effects related to fibrates therapy in PBC, with a reported incidence of $25 \%$ and $15 \%$, respectively. ${ }^{190} \mathrm{In}$ the pilot study reported from the US, one out of 20 PBC patients developed ulcerative esophagitis, possibly related to treatment with fenofibrate. ${ }^{190}$ Elevated serum transaminases ( $2-5$ times the ULN) have been reported $(\sim 10 \%)$, but these events are usually transient, lasting a few weeks, and rarely lead to discontinuation of the drug. ${ }^{190}$

The long-term use ( $\sim 9$ years) of combination therapy of UDCA and bezafibrate in PBC patients with inadequate response to UDCA has been associated with increased serum creatinine levels, ${ }^{193}$ raising concerns for potential kidney injury due to fibrates. Although these studies have provided useful preliminary information with regard to the use of fibrates in PBC, they are criticized for small sample sizes, short-term duration of therapy, scarcity of data collected, and more importantly, lack of control groups.

\section{Glucocorticoids and PBC}

Glucocorticoids (GCs) have long been used in the treatment of numerous inflammatory and autoimmune clinical conditions such as asthma, Crohn's disease, and autoimmune hepatitis. In this review, we discuss the role of GCs, particularly budesonide, in the treatment of PBC.

\section{Rationale for use}

GCs are known to suppress the inflammation by various ways. GCs act mainly via a cytosolic GC receptor (cGCR) that binds to specific DNA-binding sites resulting in induced synthesis of anti-inflammatory molecules such as lipocortin 1 and IKB, and suppression of transcription of inflammatory genes such as IL-1, IL-2, tumor necrosis factor- $\alpha$, and interferon- $\gamma .{ }^{194}$ Moreover, the GC/cGCR complex interacts physically with NF- $\kappa B$ to block its transcriptional activity within the cell. ${ }^{195} \mathrm{NF}-\mathrm{KB}$ carries out key functions in the induction and perpetuation of inflammation such as stimulation of transcription of chemokines, inflammatory cytokines, complement proteins, cell adhesion molecules, and receptors for these molecules. ${ }^{196} \mathrm{NF}-\mathrm{KB}$ also induces transcription of cyclooxygenase 2 , an enzyme essential for prostaglandin production. ${ }^{196} \mathrm{GCs}$ suppress the dendritic cell activity, decrease the number of B-cells, attenuate B-cell progenitor proliferation, and suppress antibody production by B-cells. ${ }^{194} \mathrm{GCs}$ inhibit helper and cytotoxic T-cell activity, and suppress production of cytokines by T-cells. ${ }^{194}$ More recently, GCs have been found to improve bile flow in cholestatic conditions by upregulation of the anion exchanger 2 protein, ${ }^{197}$ which may play an important role in biliary excretion of bicarbonate.

\section{Clinical experience}

GCs have been evaluated in patients with PBC. Prednisolone use in $\mathrm{PBC}$ improves liver biochemistries, but its extensive systemic side effects hamper its long-term use. ${ }^{198,199}$ Budesonide has gained more attention recently due to its high binding affinity to GC receptors and relatively low bioavailability. ${ }^{200}$

Two randomized clinical trials have shown that the combination therapy of UDCA and budesonide was superior to UDCA alone in PBC. ${ }^{201,202}$ In particular, the combination therapy of UDCA and budesonide improved liver biochemistries and histological abnormalities compared to UDCA alone. ${ }^{201,202}$ The reduction in liver chemistries was significantly more pronounced in the combination therapy (UDCA plus budesonide) groups..$^{201,202}$ Side effects reported were acne, skin bruises, hirsutism, nausea, and weight gain. ${ }^{201,202}$

In a German study, ${ }^{201}$ the reported changes in the bone mineral density (BMD) after 2 years of treatment were not significant between the two treatment groups $(-1.74 \%$ in the UDCA plus budesonide group versus $-0.98 \%$ in the UDCA monotherapy group). In the Finnish study, ${ }^{202}$ the reported change in BMD after 3 years of treatment was not significant between the two groups (UDCA plus budesonide versus UDCA alone). In the UDCA plus budesonide group, the BMD in femoral neck and lumbar spine was decreased by $3.6 \%$ and $2.8 \%$, respectively, from the baseline. ${ }^{203}$ In the UDCA monotherapy group, the corresponding decreases were $1.9 \%$ and $0.7 \%$ from baseline. ${ }^{203}$

In a 1 year open-label study ${ }^{204}$ of 22 PBC patients with inadequate response to UDCA, the addition of budesonide resulted in marginal improvement of serum ALP and bilirubin. In this study, treatment with the combination therapy was associated with significant bone loss in the lumbar spine. ${ }^{204}$ This study ${ }^{204}$ included a small number of patients $(n=22)$ compared to the German $(n=40)^{201}$ and Finnish $(n=69)^{202}$ clinical trials, and had no comparator group. These data suggest that combination therapy of UDCA and 
budesonide is potentially safe and effective in patients with early-stage PBC, and long-term clinical trials are warranted. BMD should be regularly monitored in PBC patients on budesonide therapy. ${ }^{201-204}$ The use of budesonide in patients with advanced-stage PBC, however, has been associated with serious adverse events (mainly portal vein thrombosis). ${ }^{205}$

Combination therapy with UDCA (13-15 mg/kg body weight per day), budesonide (6 mg per day), and mycophenolate mofetil (MMF, $1 \mathrm{~g}$ per day) has been shown in a pilot study to improve the liver biochemistries and histological abnormalities in 13 out of 15 patients with non-cirrhotic PBC with significant interface hepatitis who had suboptimal response to UDCA alone. ${ }^{206}$ Taken together, these studies suggest that the UDCA-budesonide combination therapy, with or without MMF, could be considered in PBC patients with suboptimal response to UDCA alone. Patients with pre-cirrhotic-stage $\mathrm{PBC}$ are more likely to benefit from GC therapy than patients with cirrhotic-stage PBC. ${ }^{199}$ The UDCA-budesonide combination therapy is currently being evaluated in a randomized clinical trial in Europe.

\section{Other treatments in PBC}

NGM282 is an FGF-19 analog and downregulates bile acid synthesis by decreasing the expression of cholesterol $7 \alpha$-hydroxylase. NGM282 is currently being investigated in a Phase II clinical trial in patients with PBC.

The CD28/CTLA4:B7 costimulatory pathway is a crucial step in T-cell-dependent B-cell activation and is characterized by binding of CD28 and CTLA4 on T-cells to B7-1 and B7-2 on activated antigen-presenting cells (B-cells, macrophages, and dendritic cells). ${ }^{207}$ Binding of CD28 to B7-1 and B7-2 results in T-cell activation, proliferation, differentiation, and release of inflammatory cytokines. ${ }^{207}$ On the other hand, binding of CTLA4 to B7-1 and B7-2 results in inhibition of T-cell activation, proliferation, and differentiation. Abatacept, ${ }^{207}$ a fusion protein composed of the Fc portion of IgG1 fused to CTLA4, is currently being investigated in PBC patients with inadequate response to UDCA.

The ASBT (or SLC10A2), localized at the apical membrane of the cholangiocytes, ileum, and renal proximal tubules, plays an important role in maintaining the enterohepatic circulation of bile salts. ${ }^{208}$ Uptake of bile salts across the apical membrane of enterocytes is mediated by the ASBT. ${ }^{208}$ Inhibition of ASBT results in disruption of the enterohepatic circulation and increased fecal loss of bile salts. ${ }^{209}$ The resultant inhibition of uptake of bile salts at the intestinal level reduces the amount of bile salts circulating back to the liver, and this effect is thought to be of therapeutic benefit in patients suffering from cholestatic liver diseases. LUM001, a novel ASBT inhibitor, is currently being evaluated in a Phase II clinical trial in patients with PBC.

The TGR5 receptor, the first known G-protein-coupled receptor specific for bile acids, ${ }^{210}$ is distributed throughout the body organs and tissues, including the liver, and is found in Kupffer cells, liver sinusoidal endothelial cells, biliary tree, and gall bladder epithelial cells. ${ }^{211}$ Experimental studies have shown that TGR5 receptor activation results in downregulation of inflammatory responses, and ${ }^{212,213}$ stimulation of NO production, ${ }^{214}$ and bicarbonate secretion by the biliary epithelium. ${ }^{215}$ These physiological effects might have important therapeutic implications in hepatic diseases, including PBC. Several TGR5 receptor agonists are currently being developed. Clinical trials are needed to examine whether TGR5 receptor agonists have clinical efficacy in the treatment of PBC.

The nuclear receptors, constitutive androstane receptor (CAR) and PXR, participate in the regulation of genes involved in the detoxification and transportation of bile acids and bilirubin. ${ }^{216}$ Preclinical studies have shown that activation of CAR and PXR through ligands increases the expression of hepatic export systems (Mrp2, Mrp3, and Mrp4) for bile acids and bilirubin, enhances the detoxification of biliary compounds, and reduces serum levels of bilirubin and bile acids. ${ }^{217}$ The hepatic expression of the Mrp2 and Mrp3 has been shown to be enhanced only in the early stages of PBC compared to the late stages of PBC, suggesting that the lack of upregulation of these proteins contributes to the progression of PBC. ${ }^{218}$ Clearly, clinical trials are needed to test the role of CAR and PXR agonists in the treatment of PBC.

Nor-UDCA, a novel C23 homolog of UDCA, has been shown to have potent choleretic and antifibrotic effects in mouse models of liver disease. ${ }^{219-222}$ These findings might be of therapeutic significance in PBC. Currently, a clinical trial of nor-UDCA in primary sclerosing cholangitis patients is underway.

\section{Challenges in the treatment of PBC}

There are several challenges in the development and evaluation of new treatments for PBC. First, PBC is an uncommon disease and is designated as an orphan disease by the US Food and Drug Administration. The relative rarity of PBC does not easily allow enrollment of the number of study subjects needed to detect a statistically significant difference when comparing a candidate agent against a comparator (such as placebo). Consequently, the results of clinical trials are frequently based on a small group of patients, and strong 
conclusions regarding preliminary safety and efficacy data are often difficult to make. Even Phase III clinical trials in PBC are often criticized by the small number of patients enrolled for the study. For example, the Canadian multicenter randomized clinical trial, ${ }^{106}$ one of the largest trials to date in PBC, enrolled only $54.4 \%$ (222/408) of the planned number of study subjects.

$\mathrm{PBC}$ is a chronic liver disease with a variable course that often slowly progresses to fibrosis, cirrhosis, and end-stage liver disease. Natural history studies of $\mathrm{PBC}$ have shown that the estimated median survival of $\mathrm{PBC}$ is $10-15$ years. ${ }^{83,86} \mathrm{In}$ reality, $\mathrm{PBC}$ patients enrolled in clinical trials of candidate agents should be followed for at least 10 years (after an enrollment period of $\sim 3-5$ years) to determine the true effect of the new candidate agent on the clinical outcomes of the disease. This is impractical because of the difficulty in enrolling the required number of patients in a short period of time and the difficulty in retaining the study subjects for such a long period of time. . $23,224^{2}$

Another major challenge in developing an effective treatment for $\mathrm{PBC}$ is the lack of surrogate endpoints. ${ }^{225}$ There has been an intense search to identify accurate noninvasive markers that could serve as surrogate endpoints in clinical trials of PBC. ${ }^{87}$ For a surrogate endpoint to be an effective substitute for the clinical outcome of a specific disease or condition, the effects of the intervention (drug, biological agent, device, procedure, etc) on the surrogate endpoint must reliably predict the overall effect on the clinical outcome. ${ }^{226}$ Generally, surrogate endpoints can be useful in Phase II clinical trials for identifying if a new intervention is promising enough to be evaluated in a Phase III clinical trial. ${ }^{226}$ In Phase III clinical trials, the endpoint ideally should be a clinical event relevant to the patient. ${ }^{226}$ In PBC, of all the noninvasive markers, serum bilirubin is the strongest predictor of clinical outcome. ${ }^{92,154}$ Serum bilirubin levels in PBC patients tend to increase as the disease progresses. ${ }^{227}$ Thus, one might expect a favorable outcome if a new treatment results in a decrease in serum bilirubin level to the normal range and maintenance of serum bilirubin level within the normal range over a long period of time. In PBC, serum bilirubin levels tend to increase in the late stages.227 Therefore, serum bilirubin could serve as a surrogate endpoint only in patients with advanced-stage PBC. ALP as discussed previously is currently the most frequently used surrogate measure in clinical trials in PBC. The use of liver stiffness measurements (measured by transient elastography, TE) as a surrogate endpoint in clinical trials of $\mathrm{PBC}$ has been recently evaluated. TE has been shown to have high performance (diagnostic performance of 0.92 for fibrosis stage $\geq 3$, and 0.99 for fibrosis stage $=4)^{228}$ and to perform better than noninvasive markers ${ }^{228}$ in identifying any grade of fibrosis or cirrhosis in PBC. ${ }^{228-230}$ Long-term studies are needed for confirmation.

\section{Conclusion}

$\mathrm{PBC}$ is an autoimmune disease of the liver that results in destruction of the interlobular hepatic bile ducts. Currently, UDCA is the only drug approved for the treatment of PBC. UDCA improves the liver biochemistries, delays histological progression, and prolongs survival free of liver transplantation. Approximately $40 \%$ of $\mathrm{PBC}$ patients do not respond to UDCA; these patients are at high risk of serious adverse events. There are several new drugs that are currently being investigated as alternative therapeutic options in patients with PBC who fail UDCA therapy, and preliminary results from these clinical trials are promising. OCA is a first-in-class FXR agonist that showed encouraging results in a Phase III clinical trial in PBC patients who had inadequate response to UDCA. Larger controlled clinical trials are needed to determine the long-term effects of fibrates and GCs on the clinical outcomes of PBC. Studies to identify reliable surrogate endpoints are needed.

\section{Disclosure}

Dr Keith D Lindor is an unpaid advisor for Lumena and Intercept. The other authors report no conflict of interest in this work.

\section{References}

1. Silveira MG, Brunt EM, Heathcote J, Gores GJ, Lindor KD, Mayo MJ. American association for the study of liver diseases endpoints conference: design and endpoints for clinical trials in primary biliary cirrhosis. Hepatology. 2010;52:349-359.

2. Boonstra K, Beuers U, Ponsioen CY. Epidemiology of primary sclerosing cholangitis and primary biliary cirrhosis: a systematic review. J Hepatol. 2012;56:1181-1188.

3. Addison T, Gull W. On a certain affection of the skin - vitiligoidea-alpha plana, beta tuberosa. Guys Hosp Rep. 1851;7:265-276.

4. Talwalkar JA, Lindor KD. Primary biliary cirrhosis. Lancet. 2003;362: 53-61.

5. Lindor KD, Gershwin ME, Poupon R, et al; American Association for Study of Liver Diseases. Primary biliary cirrhosis. Hepatology. 2009;50:291-308.

6. European Association for the Study of the Liver. EASL clinical practice guidelines: management of cholestatic liver diseases. J Hepatol. 2009;51: 237-267.

7. Gershwin ME, Mackay IR, Sturgess A, Coppel RL. Identification and specificity of a cDNA encoding the $70 \mathrm{kd}$ mitochondrial antigen recognized in primary biliary cirrhosis. J Immunol. 1987;138:3525-3531.

8. Moteki S, Leung PS, Dickson ER, et al. Epitope mapping and reactivity of autoantibodies to the E2 component of 2-oxoglutarate dehydrogenase complex in primary biliary cirrhosis using recombinant 2-oxoglutarate dehydrogenase complex. Hepatology. 1996;23:436-444. 
9. Bowlus CL, Gershwin ME. The diagnosis of primary biliary cirrhosis. Autoimmun Rev. 2014;13:441-444.

10. Mattalia A, Quaranta S, Leung PS, et al. Characterization of antimitochondrial antibodies in health adults. Hepatology. 1998;27: 656-661.

11. Shibata M, Onozuka Y, Morizane T, et al. Prevalence of antimitochondrial antibody in Japanese corporate workers in Kanagawa prefecture. $J$ Gastroenterol. 2004;39:255-259.

12. Al-Jabri AA, Al Belushi MS, Nsanze H. Frequency and levels of autoantibodies in healthy adult Omanis. Ann Saudi Med. 2003;23: 372-375.

13. Ramos-Casals M, García-Carrasco M, Brito MP, López-Soto A, Font J. Autoimmunity and geriatrics: clinical significance of autoimmune manifestations in the elderly. Lupus. 2003;12:341-355.

14. Carey EJ. Cholestatic Liver Disease. New York: Springer; 2014.

15. Björnsson E, Kalaitzakis E, Neuhauser M, et al. Fatigue measurements in patients with primary biliary cirrhosis and the risk of mortality during follow-up. Liver Int. 2010;30:251-258.

16. Carbone M, Bufton S, Monaco A, Griffiths L, Jones DE, Neuberger JM. The effect of liver transplantation on fatigue in patients with primary biliary cirrhosis: a prospective study. J Hepatol. 2013;59:490-494.

17. Newton JL. Fatigue in primary biliary cirrhosis. Clin Liver Dis. 2008;12: 367-383;ix

18. Stanca CM, Bach N, Krause C, et al. Evaluation of fatigue in US patients with primary biliary cirrhosis. Am J Gastroenterol. 2005;100: 1104-1109.

19. Newton JL, Bhala N, Burt J, Jones DE. Characterisation of the associations and impact of symptoms in primary biliary cirrhosis using a disease specific quality of life measure. $J$ Hepatol. 2006;44:776-783.

20. Bergasa NV. Pruritus of cholestasis. In: Carstens E, Akiyama T, editors. Itch: Mechanisms and Treatment. Boca Raton, FL: 2014. Chapter 6.

21. Jones EA, Bergasa NV. The pruritus of cholestasis: from bile acids to opiate agonists. Hepatology. 1990;11:884-887.

22. Talwalkar JA, Souto E, Jorgensen RA, Lindor KD. Natural history of pruritus in primary biliary cirrhosis. Clin Gastroenterol Hepatol. 2003;1:297-302.

23. Jones EA, Bergasa NV. The pruritus of cholestasis. Hepatology. 1999; 29 : 1003-1006

24. Jones DE, Al-Rifai A, Frith J, Patanwala I, Newton JL. The independent effects of fatigue and UDCA therapy on mortality in primary biliary cirrhosis: results of a 9 year follow-up. $J$ Hepatol. 2010;53: 911-917.

25. Jones DE, Bhala N, Burt J, Goldblatt J, Prince M, Newton JL. Four year follow up of fatigue in a geographically defined primary biliary cirrhosis patient cohort. Gut. 2006;55:536-541.

26. Jones EA. Pruritus and fatigue associated with liver disease: is there a role for ondansetron? Expert Opin Pharmacother. 2008;9:645-651.

27. Jones EA, Bergasa NV. The pathogenesis and treatment of pruritus and fatigue in patients with PBC. Eur J Gastroenterol Hepatol. 1999; 11:623-631.

28. Newton JL, Gibson GJ, Tomlinson M, Wilton K, Jones D. Fatigue in primary biliary cirrhosis is associated with excessive daytime somnolence. Hepatology. 2006;44:91-98.

29. Newton JL, Pairman J, Sutcliffe K, Wilton K, Jones DE. A predictive model for fatigue and its etiologic associations in primary biliary cirrhosis. Clin Gastroenterol Hepatol. 2008;6:228-233.

30. Quarneti C, Muratori P, Lalanne C, et al. Fatigue and pruritus at onset identify a more aggressive subset of primary biliary cirrhosis. Liver Int. 2015;35:636-641.

31. Zein CO, McCullough AJ. Association between fatigue and decreased survival in primary biliary cirrhosis. Gut. 2007;56:1165-1166.

32. Bachs L, Parés A, Elena M, Piera C, Rodés J. Comparison of rifampicin with phenobarbitone for treatment of pruritus in biliary cirrhosis. Lancet. 1989;1:574-576.

33. Bergasa NV, Alling DW, Talbot TL, et al. Effects of naloxone infusions in patients with the pruritus of cholestasis. A double-blind, randomized, controlled trial. Ann Intern Med. 1995;123:161-167.
34. Bergasa NV, Alling DW, Talbot TL, Wells MC, Jones EA. Oral nalmefene therapy reduces scratching activity due to the pruritus of cholestasis: a controlled study. J Am Acad Dermatol. 1999;41:431-434.

35. Bergasa NV, Schmitt JM, Talbot TL, et al. Open-label trial of oral nalmefene therapy for the pruritus of cholestasis. Hepatology. 1998;27: 679-684.

36. Beuers U, Kremer AE, Bolier R, Elferink RP. Pruritus in cholestasis: facts and fiction. Hepatology. 2014;60:399-407.

37. Datta DV, Sherlock $\mathrm{S}$. Cholestyramine for long term relief of the pruritus complicating intrahepatic cholestasis. Gastroenterology. 1966;50: 323-332.

38. Ghent CN, Carruthers SG. Treatment of pruritus in primary biliary cirrhosis with rifampin. Results of a double-blind, crossover, randomized trial. Gastroenterology. 1988;94:488-493.

39. Podesta A, Lopez P, Terg R, et al. Treatment of pruritus of primary biliary cirrhosis with rifampin. Dig Dis Sci. 1991;36:216-220.

40. Van Itallie TB, Hashim SA, Crampton RS, Tennent DM. The treatment of pruritus and hypercholesteremia of primary biliary cirrhosis with cholestyramine. N Engl J Med. 1961;265:469-474.

41. Pells G, Mells GF, Carbone M, et al; UK-PBC Consortium. The impact of liver transplantation on the phenotype of primary biliary cirrhosis patients in the UK-PBC cohort. $J$ Hepatol. 2013;59:67-73.

42. Boberg KM, Chapman RW, Hirschfield GM, Lohse AW, Manns MP, Schrumpf E. International Autoimmune Hepatitis Group. Overlap syndromes: the international autoimmune hepatitis group (IAIHG) position statement on a controversial issue. J Hepatol. 2011;54: 374-385.

43. Chazouillères $\mathrm{O}$, Wendum D, Serfaty L, Montembault S, Rosmorduc $\mathrm{O}$, Poupon R. Primary biliary cirrhosis-autoimmune hepatitis overlap syndrome: clinical features and response to therapy. Hepatology. 1998;28:296-301.

44. Muratori P, Granito A, Pappas G, et al. The serological profile of the autoimmune hepatitis/primary biliary cirrhosis overlap syndrome. $\mathrm{Am}$ J Gastroenterol. 2009;104:1420-1425.

45. Silveira MG, Talwalkar JA, Angulo P, Lindor KD. Overlap of autoimmune hepatitis and primary biliary cirrhosis: long-term outcomes. Am J Gastroenterol. 2007;102:1244-1250.

46. Siegel JL, Luthra H, Donlinger J, Angulo P, Lindor K. Association of primary biliary cirrhosis and rheumatoid arthritis. J Clin Rheumatol. 2003;9:340-343.

47. Floreani A, Franceschet I, Cazzagon N, et al. Extrahepatic autoimmune conditions associated with primary biliary cirrhosis. Clin Rev Allergy Immunol. 2014;48(2-3):192-197.

48. Hirschfield GM, Gershwin ME. The immunobiology and pathophysiology of primary biliary cirrhosis. Annu Rev Pathol. 2013;8: 303-330.

49. Prince MI, Chetwynd A, Diggle P, Jarner M, Metcalf JV, James OF. The geographical distribution of primary biliary cirrhosis in a well-defined cohort. Hepatology. 2001;34:1083-1088.

50. Corpechot C, Chrétien Y, Chazouillères O, Poupon R. Demographic, lifestyle, medical and familial factors associated with primary biliary cirrhosis. J Hepatol. 2010;53:162-169.

51. Gershwin ME, Selmi C, Worman HJ, et al; USA PBC Epidemiology Group. Risk factors and comorbidities in primary biliary cirrhosis: a controlled interview-based study of 1032 patients. Hepatology. 2005;42: 1194-1202.

52. Parikh-Patel A, Gold EB, Worman H, Krivy KE, Gershwin ME. Risk factors for primary biliary cirrhosis in a cohort of patients from the united states. Hepatology. 2001;33:16-21.

53. Prince MI, Ducker SJ, James OF. Case-control studies of risk factors for primary biliary cirrhosis in two United Kingdom populations. Gut. 2010;59:508-512.

54. Ala A, Stanca CM, Bu-Ghanim M, et al. Increased prevalence of primary biliary cirrhosis near superfund toxic waste sites. Hepatology. 2006;43: 525-531.

55. Triger DR. Primary biliary cirrhosis: an epidemiological study. Br Med J. 1980;281:772-775. 
56. Tsuji K, Watanabe Y, Van De Water J, et al. Familial primary biliary cirrhosis in Hiroshima. J Autoimmun. 1999;13:171-178.

57. Selmi C, Lleo A, Pasini S, Zuin M, Gershwin ME. Innate immunity and primary biliary cirrhosis. Curr Mol Med. 2009;9:45-51.

58. Palmer JM, Kirby JA, Jones DE. The immunology of primary biliary cirrhosis: the end of the beginning? Clin Exp Immunol. 2002;129:191-197.

59. Lohr H, Fleischer B, Gerken G, Yeaman SJ, Meyer zum Büschenfelde KH, Manns M. Autoreactive liver-infiltrating T cells in primary biliary cirrhosis recognize inner mitochondrial epitopes and the pyruvate dehydrogenase complex. J Hepatol. 1993;18:322-327.

60. Shimoda S, Van de Water J, Ansari A, et al. Identification and precursor frequency analysis of a common $\mathrm{T}$ cell epitope motif in mitochondrial autoantigens in primary biliary cirrhosis. J Clin Invest. 1998;102:1831-1840.

61. Van de Water J, Ansari A, Prindiville T, et al. Heterogeneity of autoreactive T cell clones specific for the E2 component of the pyruvate dehydrogenase complex in primary biliary cirrhosis. J Exp Med. 1995;181:723-733.

62. Van de Water J, Ansari AA, Surh CD, et al. Evidence for the targeting by 2-oxo-dehydrogenase enzymes in the $\mathrm{T}$ cell response of primary biliary cirrhosis. J Immunol. 1991;146:89-94.

63. Van de Water J, Turchany J, Leung PS, et al. Molecular mimicry in primary biliary cirrhosis. Evidence for biliary epithelial expression of a molecule cross-reactive with pyruvate dehydrogenase complex-E2. J Clin Invest. 1993;91:2653-2664.

64. Chuang YH, Lian ZX, Tsuneyama K, et al. Increased killing activity and decreased cytokine production in NK cells in patients with primary biliary cirrhosis. J Autoimmun. 2006;26:232-240.

65. Leon MP, Bassendine MF, Gibbs P, Thick M, Kirby JA. Immunogenicity of biliary epithelium: study of the adhesive interaction with lymphocytes. Gastroenterology. 1997;112:968-977.

66. Harada K, Ozaki S, Gershwin ME, Nakanuma Y. Enhanced apoptosis relates to bile duct loss in primary biliary cirrhosis. Hepatology. 1997;26:1399-1405.

67. Corpechot C. Primary biliary cirrhosis and bile acids. Clin Res Hepatol Gastroenterol. 2012;36(Suppl 1):S13-S20.

68. Allen K, Jaeschke H, Copple BL. Bile acids induce inflammatory genes in hepatocytes: a novel mechanism of inflammation during obstructive cholestasis. Am J Pathol. 2011;178:175-186.

69. Allen K, Kim ND, Moon JO, Copple BL. Upregulation of early growth response factor- 1 by bile acids requires mitogen-activated protein kinase signaling. Toxicol Appl Pharmacol. 2010;243:63-67.

70. Lazaridis KN, Gores GJ, Lindor KD. Ursodeoxycholic acid 'mechanisms of action and clinical use in hepatobiliary disorders'. J Hepatol. 2001;35:134-146.

71. Fickert P, Fuchsbichler A, Marschall HU, et al. Lithocholic acid feeding induces segmental bile duct obstruction and destructive cholangitis in mice. Am J Pathol. 2006;168:410-422.

72. Azer SA, Coverdale SA, Byth K, Farrell GC, Stacey NH. Sequential changes in serum levels of individual bile acids in patients with chronic cholestatic liver disease. J Gastroenterol Hepatol. 1996;11:208-215.

73. Hirschfield GM, Invernizzi P. Progress in the genetics of primary biliary cirrhosis. Semin Liver Dis. 2011;31:147-156.

74. Lazaridis KN, Juran BD, Boe GM, et al. Increased prevalence of antimitochondrial antibodies in first-degree relatives of patients with primary biliary cirrhosis. Hepatology. 2007;46:785-792.

75. Invernizzi P. Human leukocyte antigen in primary biliary cirrhosis: an old story now reviving. Hepatology. 2011;54:714-723.

76. Hirschfield GM, Liu X, Han Y, et al. Variants at IRF5-TNPO3, 17q12-21 and MMEL1 are associated with primary biliary cirrhosis. Nat Genet. 2010;42:655-657.

77. Hirschfield GM, Liu X, Xu C, et al. Primary biliary cirrhosis associated with HLA, IL12A, and IL12RB2 variants. $N$ Engl J Med. 2009;360:2544-2555.

78. Invernizzi P, Selmi C, Poli F, et al; Italian PBC Genetic Study Group. Human leukocyte antigen polymorphisms in Italian primary biliary cirrhosis: a multicenter study of 664 patients and 1992 healthy controls. Hepatology. 2008;48:1906-1912.
79. Liu X, Invernizzi P, Lu Y, et al. Genome-wide meta-analyses identify three loci associated with primary biliary cirrhosis. Nat Genet. 2010;42: 658-660.

80. Mells GF, Floyd JA, Morley KI, et al. UK PBC Consortium, Wellcome Trust Case Control Consortium 3. Genome-wide association study identifies 12 new susceptibility loci for primary biliary cirrhosis. Nat Genet. 2011;43:329-332.

81. Christensen E, Crowe J, Doniach D, et al. Clinical pattern and course of disease in primary biliary cirrhosis based on an analysis of 236 patients. Gastroenterology. 1980;78:236-246.

82. Mahl TC, Shockcor W, Boyer JL. Primary biliary cirrhosis: survival of a large cohort of symptomatic and asymptomatic patients followed for 24 years. J Hepatol. 1994;20:707-713.

83. Pares A, Rodes J. Natural history of primary biliary cirrhosis. Clin Liver Dis. 2003;7:779-794.

84. Prince MI, Chetwynd A, Craig WL, Metcalf JV, James OF. Asymptomatic primary biliary cirrhosis: clinical features, prognosis, and symptom progression in a large population based cohort. Gut. 2004;53:865-870.

85. Springer J, Cauch-Dudek K, O'Rourke K, Wanless IR, Heathcote EJ. Asymptomatic primary biliary cirrhosis: a study of its natural history and prognosis. Am J Gastroenterol. 1999;94:47-53.

86. Prince M, Chetwynd A, Newman W, Metcalf JV, James OF. Survival and symptom progression in a geographically based cohort of patients with primary biliary cirrhosis: follow-up for up to 28 years. Gastroenterology. 2002;123:1044-1051.

87. Lammers WJ, van Buuren HR, Hirschfield GM, et al; Global PBC Study Group. Levels of alkaline phosphatase and bilirubin are surrogate endpoints of outcomes of patients with primary biliary cirrhosis an international follow-up study. Gastroenterology. 2014;47(6): 1338.e-1349.e.

88. Bonnand AM, Heathcote EJ, Lindor KD, Poupon RE. Clinical significance of serum bilirubin levels under ursodeoxycholic acid therapy in patients with primary biliary cirrhosis. Hepatology. 1999;29:39-43.

89. Corpechot C, Abenavoli L, Rabahi N, et al. Biochemical response to ursodeoxycholic acid and long-term prognosis in primary biliary cirrhosis. Hepatology. 2008;48:871-877.

90. Rydning A, Schrumpf E, Abdelnoor M, Elgjo K, Jenssen E. Factors of prognostic importance in primary biliary cirrhosis. Scand $J$ Gastroenterol. 1990;25:119-126.

91. Wesierska-Gadek J, Penner E, Battezzati PM, et al. Correlation of initial autoantibody profile and clinical outcome in primary biliary cirrhosis. Hepatology. 2006;43:1135-1144.

92. Shapiro JM, Smith H, Schaffner F. Serum bilirubin: a prognostic factor in primary biliary cirrhosis. Gut. 1979;20:137-140.

93. Trivedi PJ, Lammers WJ, van Buuren HR, et al; On behalf of the Global PBC Study Group. Stratification of hepatocellular carcinoma risk in primary biliary cirrhosis: a multicentre international study. Gut. 2015; pii:gutjnl-2014-308351.

94. Gores GJ, Wiesner RH, Dickson ER, Zinsmeister AR, Jorgensen RA, Langworthy A. Prospective evaluation of esophageal varices in primary biliary cirrhosis: development, natural history, and influence on survival. Gastroenterology. 1989;96:1552-1559.

95. Neuberger J. Liver transplantation for primary biliary cirrhosis: indications and risk of recurrence. J Hepatol. 2003;39:142-148.

96. Tinmouth J, Tomlinson G, Heathcote EJ, Lilly L. Benefit of transplantation in primary biliary cirrhosis between 1985-1997. Transplantation. 2002;73:224-227.

97. Imam MH, Silveira MG, Sinakos E, et al. Long-term outcomes of patients with primary biliary cirrhosis and hepatocellular carcinoma. Clin Gastroenterol Hepatol. 2012;10:182-185.

98. Deutsch M, Papatheodoridis GV, Tzakou A, Hadziyannis SJ. Risk of hepatocellular carcinoma and extrahepatic malignancies in primary biliary cirrhosis. Eur J Gastroenterol Hepatol. 2008;20:5-9.

99. Jones DE, Metcalf JV, Collier JD, Bassendine MF, James OF. Hepatocellular carcinoma in primary biliary cirrhosis and its impact on outcomes. Hepatology. 1997;26:1138-1142. 
100. Silveira MG, Suzuki A, Lindor KD. Surveillance for hepatocellular carcinoma in patients with primary biliary cirrhosis. Hepatology. 2008;48:1149-1156.

101. Suzuki A, Lymp J, Donlinger J, Mendes F, Angulo P, Lindor K. Clinical predictors for hepatocellular carcinoma in patients with primary biliary cirrhosis. Clin Gastroenterol Hepatol. 2007;5:259-264.

102. Tomiyama Y, Takenaka K, Kodama T, et al. Risk factors for survival and the development of hepatocellular carcinoma in patients with primary biliary cirrhosis. Intern Med. 2013;52:1553-1559.

103. Angulo P, Batts KP, Therneau TM, Jorgensen RA, Dickson ER, Lindor KD. Long-term ursodeoxycholic acid delays histological progression in primary biliary cirrhosis. Hepatology. 1999;29: 644-647.

104. Batts KP, Jorgensen RA, Dickson ER, Lindor KD. Effects of ursodeoxycholic acid on hepatic inflammation and histological stage in patients with primary biliary cirrhosis. Am J Gastroenterol. 1996;91:2314-2317.

105. Combes B, Carithers RL Jr, Maddrey WC, et al. A randomized, doubleblind, placebo-controlled trial of ursodeoxycholic acid in primary biliary cirrhosis. Hepatology. 1995;22:759-766.

106. Heathcote EJ, Cauch-Dudek K, Walker V, et al. The Canadian multicenter double-blind randomized controlled trial of ursodeoxycholic acid in primary biliary cirrhosis. Hepatology. 1994;19: 1149-1156.

107. Lindor KD, Dickson ER, Baldus WP, et al. Ursodeoxycholic acid in the treatment of primary biliary cirrhosis. Gastroenterology. 1994;106: 1284-1290.

108. Poupon RE, Balkau B, Eschwège E, Poupon R. A multicenter, controlled trial of ursodiol for the treatment of primary biliary cirrhosis. UDCA-PBC study group. $N$ Engl J Med. 1991;324:1548-1554.

109. Poupon RE, Lindor KD, Cauch-Dudek K, Dickson ER, Poupon R, Heathcote EJ. Combined analysis of randomized controlled trials of ursodeoxycholic acid in primary biliary cirrhosis. Gastroenterology. 1997;113:884-890.

110. Poupon RE, Poupon R, Balkau B. Ursodiol for the long-term treatment of primary biliary cirrhosis. The UDCA-PBC Study Group. $N$ Engl $J$ Med. 1994;330:1342-1347.

111. Lindor KD, Jorgensen RA, Therneau TM, Malinchoc M, Dickson ER. Ursodeoxycholic acid delays the onset of esophageal varices in primary biliary cirrhosis. Mayo Clin Proc. 1997;72:1137-1140.

112. Roma MG, Toledo FD, Boaglio AC, Basiglio CL, Crocenzi FA, Sánchez Pozzi EJ. Ursodeoxycholic acid in cholestasis: linking action mechanisms to therapeutic applications. Clin Sci (Lond). 2011;121: 523-544.

113. Hofmann AF. Pharmacology of ursodeoxycholic acid, an enterohepatic drug. Scand J Gastroenterol Suppl. 1994;204:1-15.

114. Setchell KD, Rodrigues CM, Clerici C, et al. Bile acid concentrations in human and rat liver tissue and in hepatocyte nuclei. Gastroenterology. 1997;112:226-235.

115. Fickert P, Zollner G, Fuchsbichler A, et al. Effects of ursodeoxycholic and cholic acid feeding on hepatocellular transporter expression in mouse liver. Gastroenterology. 2001;121:170-183.

116. Zollner G, Wagner M, Moustafa T, et al. Coordinated induction of bile acid detoxification and alternative elimination in mice: role of FXR-regulated organic solute transporter-alpha/beta in the adaptive response to bile acids. Am J Physiol Gastrointest Liver Physiol. 2006;290:G923-G932.

117. Salvioli G, Lugli R, Pradelli JM, Frignani A, Boccalletti V. Urinary excretion of bile acids during acute administration in man. Eur J Clin Invest. 1988;18:22-28.

118. Takikawa H, Beppu T, Seyama Y. Urinary concentrations of bile acid glucuronides and sulfates in hepatobiliary diseases. Gastroenterol Jpn. 1984;19:104-109.

119. Schuetz EG, Strom S, Yasuda K, et al. Disrupted bile acid homeostasis reveals an unexpected interaction among nuclear hormone receptors, transporters, and cytochrome P450. J Biol Chem. 2001;276: 39411-39418.
120. Matern S, Matern H, Farthmann EH, Gerok W. Hepatic and extrahepatic glucuronidation of bile acids in man. Characterization of bile acid uridine $5^{\prime}$-diphosphate-glucuronosyltransferase in hepatic, renal, and intestinal microsomes. J Clin Invest. 1984;74:402-410.

121. Huang J, Bathena SP, Tong J, Roth M, Hagenbuch B, Alnouti Y. Kinetic analysis of bile acid sulfation by stably expressed human sulfotransferase 2A1 (SULT2A1). Xenobiotica. 2010;40:184-194.

122. Zollner G, Fickert P, Fuchsbichler A, et al. Role of nuclear bile acid receptor, FXR, in adaptive $\mathrm{ABC}$ transporter regulation by cholic and ursodeoxycholic acid in mouse liver, kidney and intestine. J Hepatol. 2003;39:480-488.

123. Renner EL, Lake JR, Cragoe EJ Jr, Van Dyke RW, Scharschmidt BF. Ursodeoxycholic acid choleresis: relationship to biliary HCO-3 and effects of Na+-H+ exchange inhibitors. Am J Physiol. 1988;254: G232-G241.

124. Knyrim K, Vakil N, Pfab R, Classen M. The effects of intraduodenal bile acid administration on biliary secretion of ionized calcium and carbonate in man. Hepatology. 1989;10:134-142.

125. Úriz M, Sáez E, Prieto J, Medina JF, Banales JM. Ursodeoxycholic acid is conjugated with taurine to promote secretin-stimulated biliary hydrocholeresis in the normal rat. PLoS One. 2011;6:e28717.

126. Beuers U, Hohenester S, de Buy Wenniger LJ, Kremer AE, Jansen PL, Elferink RP. The biliary $\mathrm{HCO}(3)(-)$ umbrella: a unifying hypothesis on pathogenetic and therapeutic aspects of fibrosing cholangiopathies. Hepatology. 2010;52:1489-1496.

127. Yoshikawa M, Tsujii T, Matsumura K, et al. Immunomodulatory effects of ursodeoxycholic acid on immune responses. Hepatology. 1992;16:358-364.

128. Lacaille F, Paradis K. The immunosuppressive effect of ursodeoxycholic acid: a comparative in vitro study on human peripheral blood mononuclear cells. Hepatology. 1993;18:165-172.

129. Neuman M, Angulo P, Malkiewicz I, et al. Tumor necrosis factoralpha and transforming growth factor-beta reflect severity of liver damage in primary biliary cirrhosis. $J$ Gastroenterol Hepatol. 2002;17:196-202.

130. Okada K, Shoda J, Taguchi K, et al. Ursodeoxycholic acid stimulates Nrf2-mediated hepatocellular transport, detoxification, and antioxidative stress systems in mice. Am J Physiol Gastrointest Liver Physiol. 2008;295:G735-G747.

131. Ishizaki K, Iwaki T, Kinoshita S, et al. Ursodeoxycholic acid protects concanavalin A-induced mouse liver injury through inhibition of intrahepatic tumor necrosis factor-alpha and macrophage inflammatory protein-2 production. Eur J Pharmacol. 2008;578:57-64.

132. Shah SA, Volkov Y, Arfin Q, Abdel-Latif MM, Kelleher D. Ursodeoxycholic acid inhibits interleukin 1 beta [corrected] and deoxycholic acid-induced activation of NF-kappaB and AP-1 in human colon cancer cells. Int J Cancer. 2006;118:532-539.

133. Calmus Y, Gane P, Rouger P, Poupon R. Hepatic expression of class I and class II major histocompatibility complex molecules in primary biliary cirrhosis: effect of ursodeoxycholic acid. Hepatology. 1990;11:12-15.

134. Terasaki S, Nakanuma Y, Ogino H, Unoura M, Kobayashi K. Hepatocellular and biliary expression of HLA antigens in primary biliary cirrhosis before and after ursodeoxycholic acid therapy. Am J Gastroenterol. 1991;86:1194-1199.

135. Yokomori H, Oda M, Wakabayashi G, Kitajima M, Ishii H. Ursodeoxycholic acid therapy attenuated expression of adhesion molecule in primary biliary cirrhosis. Intern Med. 2003;42:1259-1261.

136. Pares A, Caballeria L, Rodes J. Excellent long-term survival in patients with primary biliary cirrhosis and biochemical response to ursodeoxycholic acid. Gastroenterology. 2006;130:715-720.

137. Angulo P, Lindor KD, Therneau TM, et al. Utilization of the mayo risk score in patients with primary biliary cirrhosis receiving ursodeoxycholic acid. Liver. 1999;19:115-121.

138. Momah N, Silveira MG, Jorgensen R, Sinakos E, Lindor KD. Optimizing biochemical markers as endpoints for clinical trials in primary biliary cirrhosis. Liver Int. 2012;32:790-795. 
139. Kuiper EM, Hansen BE, de Vries RA, et al; Dutch PBC Study Group. Improved prognosis of patients with primary biliary cirrhosis that have a biochemical response to ursodeoxycholic acid. Gastroenterology. 2009; $136: 1281-1287$.

140. Corpechot C, Chazouilleres O, Poupon R. Early primary biliary cirrhosis: biochemical response to treatment and prediction of longterm outcome. J Hepatol. 2011;55:1361-1367.

141. Kumagi T, Guindi M, Fischer SE, et al. Baseline ductopenia and treatment response predict long-term histological progression in primary biliary cirrhosis. Am J Gastroenterol. 2010;105:2186-2194.

142. Evans RM. The steroid and thyroid hormone receptor superfamily. Science. 1988;240:889-895.

143. Fan M, Wang X, Xu G, Yan Q, Huang W. Bile acid signaling and liver regeneration. Biochim Biophys Acta. 2014;1849(2):196-200.

144. Makishima M, Okamoto AY, Repa JJ, et al. Identification of a nuclear receptor for bile acids. Science. 1999;284:1362-1365.

145. Huang W, Ma K, Zhang J, et al. Nuclear receptor-dependent bile acid signaling is required for normal liver regeneration. Science. 2006;312:233-236

146. Miyata M, Sakaida Y, Matsuzawa H, Yoshinari K, Yamazoe Y. Fibroblast growth factor 19 treatment ameliorates disruption of hepatic lipid metabolism in farnesoid X receptor (Fxr)-null mice. Biol Pharm Bull. 2011;34:1885-1889.

147. Fu L, John LM, Adams SH, et al. Fibroblast growth factor 19 increases metabolic rate and reverses dietary and leptin-deficient diabetes. Endocrinology. 2004;145:2594-2603.

148. Holt JA, Luo G, Billin AN, et al. Definition of a novel growth factordependent signal cascade for the suppression of bile acid biosynthesis. Genes Dev. 2003;17:1581-1591.

149. Kanda T, Foucand L, Nakamura Y, et al. Regulation of expression of human intestinal bile acid-binding protein in Caco-2 cells. Biochem J. 1998;330(pt 1):261-265.

150. Gong YZ, Everett ET, Schwartz DA, Norris JS, Wilson FA. Molecular cloning, tissue distribution, and expression of a $14-\mathrm{kDa}$ bile acidbinding protein from rat ileal cytosol. Proc Natl Acad Sci U S A. 1994;91:4741-4745.

151. Fiorucci S, Antonelli E, Rizzo G, et al. The nuclear receptor SHP mediates inhibition of hepatic stellate cells by FXR and protects against liver fibrosis. Gastroenterology. 2004;127:1497-1512.

152. Pellicciari R, Fiorucci S, Camaioni E, et al. 6alpha-ethyl-chenodeoxycholic acid (6-ECDCA), a potent and selective FXR agonist endowed with anticholestatic activity. J Med Chem. 2002;45:3569-3572.

153. Hirschfield GM, Mason A, Luketic V, et al. Efficacy of obeticholic acid in patients with primary biliary cirrhosis and inadequate response to ursodeoxycholic acid. Gastroenterology. 2015;148(751-61):e8.

154. Wiesner RH, Porayko MK, Dickson ER, et al. Selection and timing of liver transplantation in primary biliary cirrhosis and primary sclerosing cholangitis. Hepatology. 1992;16:1290-1299.

155. Ghonem NS, Assis DN, Boyer JL. On fibrates and cholestasis: a review. Hepatology. 2015;62(2):635-643.

156. Ghonem NS, Boyer JL. Fibrates as adjuvant therapy for chronic cholestatic liver disease: its time has come. Hepatology. 2013;57: 1691-1693.

157. Willson TM, Brown PJ, Sternbach DD, Henke BR. The PPARs: from orphan receptors to drug discovery. J Med Chem. 2000;43: $527-550$.

158. Duval C, Fruchart JC, Staels B. PPAR alpha, fibrates, lipid metabolism and inflammation. Arch Mal Coeur Vaiss. 2004;97:665-672.

159. Thomas M, Burk O, Klumpp B, et al. Direct transcriptional regulation of human hepatic cytochrome P450 3A4 (CYP3A4) by peroxisome proliferator-activated receptor alpha (PPARalpha). Mol Pharmacol. 2013;83:709-718.

160. Iwasaki S, Tsuda K, Ueta H. Bezafibrate may have a beneficial effect in pre-cirrhotic primary biliary cirrhosis. Hepatol Res. 1999;16:12-18.

161. Halliday JS, Chapman RW. No more pilots, a phase III trial of fibrates in primary biliary cirrhosis is long overdue! J Gastroenterol Hepatol. 2011;26:1345-1346.
162. Post SM, Duez H, Gervois PP, Staels B, Kuipers F, Princen HM. Fibrates suppress bile acid synthesis via peroxisome proliferatoractivated receptor-alpha-mediated downregulation of cholesterol 7alpha-hydroxylase and sterol 27-hydroxylase expression. Arterioscler Thromb Vasc Biol. 2001;21:1840-1845.

163. Barbier O, Duran-Sandoval D, Pineda-Torra I, Kosykh V, Fruchart JC, Staels B. Peroxisome proliferator-activated receptor alpha induces hepatic expression of the human bile acid glucuronidating UDP-glucuronosyltransferase 2B4 enzyme. J Biol Chem. 2003;278:32852-32860.

164. Fang HL, Strom SC, Cai H, Falany CN, Kocarek TA, Runge-Morris M. Regulation of human hepatic hydroxysteroid sulfotransferase gene expression by the peroxisome proliferator-activated receptor alpha transcription factor. Mol Pharmacol. 2005;67:1257-1267.

165. Jung D, Fried M, Kullak-Ublick GA. Human apical sodiumdependent bile salt transporter gene (SLC10A2) is regulated by the peroxisome proliferator-activated receptor alpha. J Biol Chem. 2002;277:30559-30566

166. Ghonem NS, Ananthanarayanan M, Soroka CJ, Boyer JL. Peroxisome proliferator-activated receptor alpha activates human multidrug resistance transporter 3/ATP-binding cassette protein subfamily B4 transcription and increases rat biliary phosphatidylcholine secretion. Hepatology. 2014;59:1030-1042.

167. Delerive P, Gervois P, Fruchart JC, Staels B. Induction of IkappaBalpha expression as a mechanism contributing to the anti-inflammatory activities of peroxisome proliferator-activated receptor-alpha activators. J Biol Chem. 2000;275:36703-36707.

168. Mennone A, Soroka CJ, Cai SY, et al. Mrp4-/- mice have an impaired cytoprotective response in obstructive cholestasis. Hepatology. 2006;43:1013-1021.

169. Chai J, He Y, Cai SY, et al. Elevated hepatic multidrug resistanceassociated protein 3/ATP-binding cassette subfamily C 3 expression in human obstructive cholestasis is mediated through tumor necrosis factor alpha and c-Jun NH2-terminal kinase/stress-activated protein kinase-signaling pathway. Hepatology. 2012;55:1485-1494.

170. Singh VK, Mehrotra S, Narayan P, Pandey CM, Agarwal SS. Modulation of autoimmune diseases by nitric oxide. Immunol Res. 2000;22: $1-19$.

171. Sanz-Cameno P, Medina J, García-Buey L, et al. Enhanced intrahepatic inducible nitric oxide synthase expression and nitrotyrosine accumulation in primary biliary cirrhosis and autoimmune hepatitis. J Hepatol. 2002;37:723-729.

172. Hokari A, Zeniya M, Esumi H, Kawabe T, Gershwin ME, Toda G. Detection of serum nitrite and nitrate in primary biliary cirrhosis: possible role of nitric oxide in bile duct injury. J Gastroenterol Hepatol. 2002;17:308-315.

173. Battista S, Bar F, Mengozzi G, et al. Evidence of an increased nitric oxide production in primary biliary cirrhosis. Am J Gastroenterol. 2001;96:869-875.

174. Akbar SM, Furukawa S, Nakanishi S, Abe M, Horiike N, Onji M. Therapeutic efficacy of decreased nitrite production by bezafibrate in patients with primary biliary cirrhosis. $J$ Gastroenterol. 2005;40:157-163.

175. Hirano Y, Hirano F, Fujii H, Makino I. Fibrates suppress chenodeoxycholic acid-induced RANTES expression through inhibition of NF-kappaB activation. Eur J Pharmacol. 2002;448:19-26.

176. Zhang $\mathrm{B}, \mathrm{Hu} \mathrm{M}$, Zhang $\mathrm{P}$, et al. BAFF promotes regulatory T-cell apoptosis and blocks cytokine production by activating B cells in primary biliary cirrhosis. Braz J Med Biol Res. 2013;46:433-439.

177. Ohmoto K, Yoshioka N, Yamamoto S. Long-term effect of bezafibrate on parameters of hepatic fibrosis in primary biliary cirrhosis. J Gastroenterol. 2006;41:502-503.

178. Honda A, Ikegami T, Nakamuta M, et al. Anticholestatic effects of bezafibrate in patients with primary biliary cirrhosis treated with ursodeoxycholic acid. Hepatology. 2013;57:1931-1941.

179. Hazzan R, Tur-Kaspa R. Bezafibrate treatment of primary biliary cirrhosis following incomplete response to ursodeoxycholic acid. J Clin Gastroenterol. 2010;44:371-373. 
180. Kanda T, Yokosuka O, Imazeki F, Saisho H. Bezafibrate treatment: a new medical approach for PBC patients? J Gastroenterol. 2003;38: 573-578.

181. Kurihara T, Maeda A, Shigemoto M, Yamashita K, Hashimoto E. Investigation into the efficacy of bezafibrate against primary biliary cirrhosis, with histological references from cases receiving long term monotherapy. Am J Gastroenterol. 2002;97:212-214.

182. Kurihara T, Niimi A, Maeda A, Shigemoto M, Yamashita K. Bezafibrate in the treatment of primary biliary cirrhosis: comparison with ursodeoxycholic acid. Am J Gastroenterol. 2000;95:2990-2992.

183. Lens S, Leoz M, Nazal L, Bruguera M, Parés A. Bezafibrate normalizes alkaline phosphatase in primary biliary cirrhosis patients with incomplete response to ursodeoxycholic acid. Liver Int. 2014;34:197-203.

184. Nakai S, Masaki T, Kurokohchi K, Deguchi A, Nishioka M. Combination therapy of bezafibrate and ursodeoxycholic acid in primary biliary cirrhosis: a preliminary study. Am J Gastroenterol. 2000;95: 326-327.

185. Ohmoto K, Mitsui Y, Yamamoto S. Effect of bezafibrate in primary biliary cirrhosis: a pilot study. Liver. 2001;21:223-224.

186. Takeuchi Y, Ikeda F, Fujioka S, et al. Additive improvement induced by bezafibrate in patients with primary biliary cirrhosis showing refractory response to ursodeoxycholic acid. J Gastroenterol Hepatol. 2011;26:1395-1401.

187. Yano K, Kato H, Morita S, Takahara O, Ishibashi H, Furukawa R. Is bezafibrate histologically effective for primary biliary cirrhosis? Am J Gastroenterol. 2002;97:1075-1077.

188. Dohmen K, Mizuta T, Nakamuta M, Shimohashi N, Ishibashi H, Yamamoto K. Fenofibrate for patients with asymptomatic primary biliary cirrhosis. World J Gastroenterol. 2004;10:894-898.

189. Han XF, Wang QX, Liu Y, et al. Efficacy of fenofibrate in Chinese patients with primary biliary cirrhosis partially responding to ursodeoxycholic acid therapy. J Dig Dis. 2012;13:219-224.

190. Levy C, Peter JA, Nelson DR, et al. Pilot study: fenofibrate for patients with primary biliary cirrhosis and an incomplete response to ursodeoxycholic acid. Aliment Pharmacol Ther. 2011;33:235-242.

191. Liberopoulos EN, Florentin M, Elisaf MS, Mikhailidis DP, Tsianos E. Fenofibrate in primary biliary cirrhosis: a pilot study. Open Cardiovasc Med J. 2010;4:120-126.

192. Ohira H, Sato Y, Ueno T, Sata M. Fenofibrate treatment in patients with primary biliary cirrhosis. Am J Gastroenterol. 2002;97:2147-2149.

193. Hosonuma K, Sato K, Yamazaki Y, et al. A prospective randomized controlled study of long-term combination therapy using ursodeoxycholic acid and bezafibrate in patients with primary biliary cirrhosis and dyslipidemia. Am J Gastroenterol. 2015;110:423-431.

194. Baschant U, Tuckermann J. The role of the glucocorticoid receptor in inflammation and immunity. J Steroid Biochem Mol Biol. 2010;120: 69-75.

195. McKay LI, Cidlowski JA. Molecular control of immune/inflammatory responses: interactions between nuclear factor-kappa B and steroid receptor-signaling pathways. Endocr Rev. 1999;20:435-459.

196. Martini L. Encyclopedia of Endocrine Diseases. Amsterdam; Boston: Elsevier Academic Press; 2004.

197. Arenas F, Hervias I, Uriz M, Joplin R, Prieto J, Medina JF. Combination of ursodeoxycholic acid and glucocorticoids upregulates the AE2 alternate promoter in human liver cells. J Clin Invest. 2008;118: 695-709.

198. Leuschner M, Güldütuna S, You T, Hübner K, Bhatti S, Leuschner U. Ursodeoxycholic acid and prednisolone versus ursodeoxycholic acid and placebo in the treatment of early stages of primary biliary cirrhosis. J Hepatol. 1996;25:49-57.

199. Mitchison HC, Bassendine MF, Malcolm AJ, Watson AJ, Record CO, James OF. A pilot, double-blind, controlled 1-year trial of prednisolone treatment in primary biliary cirrhosis: hepatic improvement but greater bone loss. Hepatology. 1989;10:420-429.

200. Mollmann HW, Barth M. Glucocorticoid Therapy in Chronic Inflammatory Bowel Disease. From Basic Principles to Rational Therapy. Boston: Kluwer; 1996.
201. Leuschner M, Maier KP, Schlichting J, et al. Oral budesonide and ursodeoxycholic acid for treatment of primary biliary cirrhosis: results of a prospective double-blind trial. Gastroenterology. 1999;117: 918-925.

202. Rautiainen H, Kärkkäinen P, Karvonen AL, et al. Budesonide combined with UDCA to improve liver histology in primary biliary cirrhosis: a three-year randomized trial. Hepatology. 2005;41:747-752.

203. Rautiainen H, Färkkilä M, Neuvonen M, et al. Pharmacokinetics and bone effects of budesonide in primary biliary cirrhosis. Aliment Pharmacol Ther. 2006;24:1545-1552.

204. Angulo P, Jorgensen RA, Keach JC, Dickson ER, Smith C, Lindor KD. Oral budesonide in the treatment of patients with primary biliary cirrhosis with a suboptimal response to ursodeoxycholic acid. Hepatology. 2000;31:318-323.

205. Hempfling W, Grunhage F, Dilger K, Reichel C, Beuers U, Sauerbruch T. Pharmacokinetics and pharmacodynamic action of budesonide in early- and late-stage primary biliary cirrhosis. Hepatology. 2003;38:196-202.

206. Rabahi N, Chrétien Y, Gaouar F, et al. Triple therapy with ursodeoxycholic acid, budesonide and mycophenolate mofetil in patients with features of severe primary biliary cirrhosis not responding to ursodeoxycholic acid alone. Gastroenterol Clin Biol. 2010;34:283-287.

207. Dall'Era M, Davis J. CTLA4Ig: a novel inhibitor of costimulation. Lupus. 2004;13:372-376.

208. Anwer MS, Stieger B. Sodium-dependent bile salt transporters of the SLC10A transporter family: more than solute transporters. Pflugers Arch. 2014;466:77-89.

209. Potter GD. Bile acid diarrhea. Dig Dis. 1998;16:118-124.

210. Maruyama T, Miyamoto Y, Nakamura T, et al. Identification of membrane-type receptor for bile acids (M-BAR). Biochem Biophys Res Commun. 2002;298:714-719.

211. Duboc H, Tache Y, Hofmann AF. The bile acid TGR5 membrane receptor: from basic research to clinical application. Dig Liver Dis. 2014;46:302-312.

212. Kawamata Y, Fujii R, Hosoya M, et al. A G protein-coupled receptor responsive to bile acids. J Biol Chem. 2003;278:9435-9440.

213. Keitel V, Donner M, Winandy S, Kubitz R, Häussinger D. Expression and function of the bile acid receptor TGR5 in Kupffer cells. Biochem Biophys Res Commun. 2008;372:78-84.

214. Keitel V, Reinehr R, Gatsios P, et al. The G-protein coupled bile salt receptor TGR5 is expressed in liver sinusoidal endothelial cells. Hepatology. 2007;45:695-704.

215. Keitel V, Ullmer C, Haussinger D. The membrane-bound bile acid receptor TGR5 (Gpbar-1) is localized in the primary cilium of cholangiocytes. Biol Chem. 2010;391:785-789.

216. Trauner M, Wagner M, Fickert P, Zollner G. Molecular regulation of hepatobiliary transport systems: clinical implications for understanding and treating cholestasis. J Clin Gastroenterol. 2005;39:S111-S124.

217. Wagner M, Halilbasic E, Marschall HU, et al. CAR and PXR agonists stimulate hepatic bile acid and bilirubin detoxification and elimination pathways in mice. Hepatology. 2005;42:420-430.

218. Takeyama Y, Uehara Y, Inomata S, et al. Alternative transporter pathways in patients with untreated early-stage and late-stage primary biliary cirrhosis. Liver Int. 2009;29:406-414.

219. Hofmann AF, Zakko SF, Lira M, et al. Novel biotransformation and physiological properties of norursodeoxycholic acid in humans. Hepatology. 2005;42:1391-1398.

220. Fickert P, Wagner M, Marschall HU, et al. 24-norUrsodeoxycholic acid is superior to ursodeoxycholic acid in the treatment of sclerosing cholangitis in Mdr2 (Abcb4) knockout mice. Gastroenterology. 2006;130:465-481.

221. Fickert P, Pollheimer MJ, Silbert D, et al. Differential effects of norUDCA and UDCA in obstructive cholestasis in mice. $J$ Hepatol. 2013;58:1201-1208.

222. Sombetzki M, Fuchs CD, Fickert P, et al. 24-nor-ursodeoxycholic acid ameliorates inflammatory response and liver fibrosis in a murine model of hepatic schistosomiasis. J Hepatol. 2015;62:871-878. 
223. Gong Y, Huang Z, Christensen E, Gluud C. Ursodeoxycholic acid for patients with primary biliary cirrhosis: an updated systematic review and meta-analysis of randomized clinical trials using Bayesian approach as sensitivity analyses. Am J Gastroenterol. 2007;102: 1799-1807.

224. Goulis J, Leandro G, Burroughs AK. Randomised controlled trials of ursodeoxycholic-acid therapy for primary biliary cirrhosis: a metaanalysis. Lancet. 1999;354:1053-1060.

225. Giljaca V, Stimac D, Gluud C. Are levels of alkaline phosphatases and bilirubin surrogate markers of outcomes of patients with primary biliary cirrhosis? Gastroenterology. 2015;148:860.

226. Fleming TR, DeMets DL. Surrogate end points in clinical trials: are we being misled? Ann Intern Med. 1996;125:605-613.
227. Mayo MJ, Parkes J, Adams-Huet B, et al. Prediction of clinical outcomes in primary biliary cirrhosis by serum enhanced liver fibrosis assay. Hepatology. 2008;48:1549-1557.

228. Floreani A, Cazzagon N, Martines D, Cavalletto L, Baldo V, Chemello L. Performance and utility of transient elastography and noninvasive markers of liver fibrosis in primary biliary cirrhosis. Dig Liver Dis. 2011;43:887-892.

229. Corpechot C, Carrat F, Poujol-Robert A, et al. Noninvasive elastography-based assessment of liver fibrosis progression and prognosis in primary biliary cirrhosis. Hepatology. 2012;56: 198-208.

230. Poupon R, Corpechot C. Elastography-based assessment of primary biliary cirrhosis staging. Dig Liver Dis. 2011;43:839-840

\section{Publish your work in this journal}

Orphan Drugs: Research and Reviews is an international, peer-reviewed, open access journal publishing original research, reports, reviews and commentaries on all areas of the design and development of orphan drugs for the treatment of rare diseases through to clinical applications Clinical outcomes, patient safety, and programs for the development and effective, safe, and sustained use of medicines will be a feature of the journal. The manuscript management system is completely online and includes a very quick and fair peer-review system, which is all easy to use. Visit http://www.dovepress.com/testimonials.php to read real quotes from published authors.

Submit your manuscript here: http://www.dovepress.com/orphan-drugs-research-and-reviews-journal 